\title{
PENGARUH PARTISIPASI PENYUSUNAN ANGGARAN TERHADAP KINERJA MANAJERIAL PADA SEKOLAH MENENGAH NEGERI DI TEGAL
}

\author{
Galih Wicaksono \\ Universitas Jember \\ Galih_boyz86@yahoo.com
}

\begin{abstract}
.
This study examined the influence of budgetary participation to managerial performance through budget adequacy, organization commitment, and job relevant information as intervening variables. The population of this study is staff that budgetary participation at Public School in Tegal. The sample of this research is collected with contact person. The result of this study showed that budgetary participation has not effect to managerial performance. Other result that is shown in this study is that budgetary participation has positive effect to budget adequacy, organization commitment, and job relevant information. But, budget adequacy and job relevant information has not effect to managerial performance. Just organization commitment has positive effect to managerial performance. So, Budgetary participation has positive effect to organization commitment, and then organization commitment has positive effect to managerial performance.
\end{abstract}

Keywords : budgetary participation; budget adequacy; managerial performance.

\begin{abstract}
Abstrak.
Penelitian ini bertujuan menguji pengaruh antara partisipasi penyusunan anggaran terhadap kinerja manajerial melalui variabel kecukupan anggaran, komitmen organisasi, dan job relevant information sebagai variabel intervening. Populasi dalam penelitian ini adalah staf penyusun anggaran pada Sekolah Negeri di Kota Tegal. Sampel penelitian dikumpulkan dengan menyebar kuesioner secara langsung. Hasil penelitian menunjukkan bahwa partisipasi penyusunan anggaran tidak berpengaruh terhadap kinerja manajerial. Hasil lain yang ditunjukkan dalam penelitian ini adalah partisipasi penyusunan anggaran berpengaruh positif terhadap kecukupan anggaran, komitmen organisasi, dan job relevant information. Tetapi, kecukupan anggaran dan job relevant information tidak berpengaruh terhadap kinerja manjerial. Hanya komitmen organisasi yang berpengaruh positif terhadap kinerja manajerial. Jadi, partisipasi penyusunan anggaran berpengaruh positif terhadap komitmen organisasi, dan kemudian komitmen organisasi berpengaruh positif terhadap kinerja manajerial.
\end{abstract}

Kata Kunci: Partisipasi penyusunan anggaran; kecukupan anggaran; kinerja manajerial

Diterima: 30 Mei 2016; Direvisi: 20 Agustus 2016; Disetujui: 13 September 2016 


\section{PENDAHULUAN}

Undang-undang Nomor 20 tahun 2003 tentang Sistem Pendidikan Nasional, pada Pasal 49 (1) disebutkan bahwa Dana Pendidikan selain gaji pendidik dan biaya pendidikan kedinasan dialokasikan minimal $20 \%$ dari Anggaran Pendapatan dan Belanja Negara dan minimal 20 \% dari Anggaran Pendapatan dan Belanja (Kementerian Pendidikan Nasional, 2011). Untuk mendukung operasional sekolah, sekolah mendapatkan beberapa sumber pendanaan, diantaranya: Pertama, APBN dalam bentuk BOS, dana dekon dan bantuan lainnya. Kedua, APBD Provinsi dalam bentuk pendampingan BOS Provinsi dan bantuan lainnya. Ketiga, APBD Kabupaten atau Kota dalam bentuk program kegiatan pada Dinas Pendidikan dan pendampingan BOS Kabupaten atau Kota. Keempat, berasal dari sumbangan masyarakat yang bersifat sukarela dan tidak mengikat. Beberapa sumber pendanaan tersebut didapatkan setelah pihak Sekolah mengajukan anggaran kepada dinas atau instansi terkait. Anggaran pada dinas pendidikan dilakukan secara partisipatif, dimana dalam penyusunan anggaran melibatkan penuh kepala sekolah, bendahara, dan segenap pejabat sekolah yang ditunjuk dalam penyusunan anggaran. Diharapkan dari berbagai sumber pendanaan tersebut, akan bisa meningkatkan kinerja sekolah.

Dengan adanya partisipasi penyusunan anggaran, maka kinerja manajerial akan meningkat. Hal ini disebabkan karena beberapa hal: Pertama, partisipasi penyusunan anggaran akan menyebabkan komitmen terhadap organisasi, karena adanya rasa tanggungjawab yang timbul dimana anggaran merupakan hasil komunikasi antara atasan dan bawahan. Kedua, partisipasi dalam penyusunan anggaran akan menyebabkan terjadinya kecukupan anggaran, karena atasan melibatkan bawahan sebagai pelaksana dalam penyusunan anggaran; dan; Ketiga, partisipasi dalam penyusunan anggaran akan membuat atasan mendengarkan informasi yang berasal dari bawahan yang terkait dengan pekerjaan, sehingga atasan akan memperoleh pemahaman yang lebih baik tentang pengetahuan yang relevan dengan tugas.

Nouri dan Parker (1998) menyatakan bahwa pada awal-awal riset antara partisipasi anggaran dan kinerja manajer menunjukkan bukti yang tidak meyakinkan dan seringkali bertentangan. Hasil riset tersebut ada yang 
menunjukkan hubungan negatif secara signifikan (Campell dan Gingrich, 1986; Ivancevich, 1997 dalam Supriyono, 2004), hubungan positif secara signifikan (Early, 1985; Milani, 1975; Steers, 1975 dalam Supriyono, 2004), hubungan negatif tidak signifikan (Dosett, Latam, dan Mitcell, 1979; Mia, 1988 dalam Supriyono, 2004), dan hubungan positif tidak signifikan (Latham dan Marshall, 1982; Latham dan Yukl, 1976 dalam Supriyono, 2004). Di Indonesia, penelitian mengenai hubungan antara partisipasi penyusunan anggaran dan kinerja manajerial telah banyak dilakukan, baik pada sektor pemerintahan maupun swasta. Pada penelitian ini akan dilihat seberapa efektifkah proses partisipasi penyusunan anggaran yang dilakukan bendaharawan di Sekolah Menengah Negeri terhadap kinerja manajerial. Selain hal itu, sepanjang pengetahuan peneliti, penelitian pada organisasi sekolah masih jarang dilakukan. Kebanyakan yang diteliti adalah pada sektor Pemerintah Daerah, Rumah sakit daerah, dan Badan usaha daerah seperti PDAM.

Penelitian yang penulis lakukan bertujuan untuk menguji kembali pengaruh partisipasi penyusunan anggaran terhadap kinerja manajerial pada organisasi sektor publik, dimana sampel yang digunakan dalam penelitian ini adalah pada Sekolah Menengah Negeri di Kota Tegal. Digunakannya sampel Sekolah Menengah Negeri di Kota Tegal, karena Sekolah Menengah Negeri di Kota Tegal dalam penyusunan anggaran menggunakan partisipasi penuh dalam penyusunan anggaran, dan telah menjadi UPTD, sehingga Sekolah Menengah Negeri mendapat amanat penuh untuk mengelola keuangan dan sebagai kuasa pengguna anggaran. Masing-masing kepala sekolah bertanggungjawab langsung atas pengelolaan keuangan negara. Proses penganggaran pada Sekolah Menengah Negeri di Kota Tegal diajukan kepada beberapa pihak, antara lain kepada Pemerintah Kota Tegal, Pemerintah Provinsi Jawa Tengah, alokasi dana pendidikan dari Pemerintah Pusat di Jakarta dan sumbangan atau bantuan dari masyarakat yang bersifat sukarela dan tidak mengikat.

Penelitian tentang pengaruh partisipasi penyusunan anggaran terhadap kinerja manajerial pada Sekolah Menengah Negeri, menurut penulis sangat penting untuk dilakukan. Hal ini penting karena dengan mengetahui pengaruh partisipasi anggaran terhadap kinerja manajerial, maka diharapkan pimpinan lembaga 
pendidikan baik di daerah maupun di pusat dapat mengembangkan pendekatan dalam partisipasi anggaran untuk menentukan keputusan yang optimal demi meningkatnya kinerja manajerial di Sekolah. Dengan kinerja manajerial yang semakin meningkat, maka diharapkan kualitas pendidikan akan meningkat, sehingga akan mendorong kemajuan bagi bangsa dan negara.

Berdasarkan berbagai hal di atas, penelitian ini bertujuan untuk menganalisis apakah ada pengaruh langsung antara partisipasi penyusunan anggaran terhadap kinerja manajerial di Sekolah Menengah Negeri di Tegal. Selain itu penelitian bertujuan pula untuk menganalisis pengaruh kecukupan anggaran, komitmen organisasi, dan job relevant information merupakan intervening dalam hubungan antara partisipasi penyusunan anggaran terhadap kinerja manajerial.

\section{METODE}

Populasi dalam penelitian ini adalah para individu yang termasuk dalam perumus dan penyusun anggaran di sekolah, dimana mereka terlibat secara aktif dalam penyusunan anggaran pada Sekolah Menengah Negeri di Kota Tegal, yang meliputi: 18 Sekolah Menengah Pertama, 2 Sekolah Menengah Pertama Terbuka, 1 Madrasah Tsanawiyah, 5 Sekolah Menengah Atas, 3 Sekolah Menengah Kejuruan, dan 1 Madrasah Aliyah yang berstatus Sekolah Negeri, dimana Sekolah Negeri tersebut tidak berorientasi memperoleh laba.

Sampel dalam penelitian ini adalah para individu yang termasuk dalam tim penyusun anggaran di setiap sekolah, dimana mereka terlibat secara aktif dalam penyusunan anggaran pada Sekolah Menengah Negeri di Kota Tegal, yang berjumlah 30 Sekolah dengan menggunakan metode convinience sampling. Alasan pemilihan pengambilan sampel dengan metode convinience sampling pada Sekolah Menengah Negeri di Kota Tegal dengan pertimbangan sebagai berikut: Pertama, Sekolah Menengah Negeri dalam operasionalnya tidak berorientasi memperoleh laba, sehingga menarik untuk diteliti kinerja manajerialnya terkait dengan penyusunan anggaran yang dilakukan. Kedua, setiap sekolah diberikan 6 (enam) angket kuesioner, dimana menurut informasi yang penulis dapatkan, bahwa individu yang terlibat aktif dalam penyusunan anggaran di tiap sekolah sekitar 6 (enam) orang. Ketiga, sekolah Menengah Negeri di Kota Tegal mendapatkan 
bantuan BOS Pendamping dari Pemerintah Kota Tegal, sehingga menarik untuk diteliti terkait dengan kecukupan anggaran yang diterima.

Prosedur pengumpulan data dalam penelitian ini menggunakan data primer yang dikumpulan dengan cara mengirimkan langsung kuesioner kepada responden, dengan didistribusikan langsung ke Sekolah Menengah Negeri yang menjadi lokasi penelitian. Dalam jangka waktu satu sampai dua minggu setelah dikirim, kuesioner tersebut diambil kembali oleh peneliti. Pengiriman dan pengambilan kuesioner yang dilakukan secara langsung oleh peneliti, bertujuan untuk memperoleh tingkat pengembalian yang tinggi.

Pengujian hipotesis penelitian ini dilakukan dengan menggunakan teknik analisis Structural Equation Modelling (SEM). Adapun variabel penelitian yang dipergunakan dalam penelitian ini ialah: partisipasi penyusunan anggaran (PPA), kinerja manajerial (KM), kecukupan anggaran (KA), komitmen organisasi (KO), dan job relevant information (JRI).

Partisipasi penyusunan anggaran adalah tingkat keterlibatan dan pengaruh individu dalam proses penyusunan anggaran. Instrumen untuk mengukur variabel partisipasi dalam penganggaran mengadopsi pendapat Milani (1975). Ada 6 (enam) item pertanyaan yang digunakan, dengan rentang skor 1 (terendah) sampai dengan 5 (tertinggi).

Kinerja manajerial merupakan hasil upaya yang dilakukan manajer dalam melakukan tugas dan fungsinya dalam organisasi. Kinerja manajerial diukur dengan menggunakan instrumen daftar pertanyaan yang dikembangkan oleh Mahoney et al. (1963). Daftar pertanyaan tersebut terdiri dari 9 (sembilan) butir pertanyaan, dengan rentang skor 1 (terendah) sampai dengan 5 (tertinggi).

Kecukupan anggaran adalah suatu keadaan dimana individu percaya bahwa sumber-sumber anggarannya cukup untuk menjalankan tugas-tugasnya. Kecukupan anggaran diukur dengan 3 (tiga) item pertanyaan yang dikembangkan oleh Nouri dan Parker (1998), dengan rentang skor 1 (sangat tidak setuju) sampai dengan 5 (sangat setuju).

Komitmen organisasi adalah keadaan dimana individu memiliki kepercayaan, keterikatan, serta perasaan memiliki atas perusahaan sehingga 
individu tersebut akan mengutamakan kepentingan perusahaan dibandingkan kepentingan pribadi. Instrumen untuk mengukur komitmen organisasi yaitu dengan menggunakan instrumen pertanyaan yang dikembangkan oleh Mowday et al (1979). Pertanyaan ini terdiri dari 9 (sembilan) pertanyaan, dengan rentang skor 1 (sangat tidak setuju) sampai dengan 5 (sangat setuju).

Job relevant information adalah informasi yang tersedia bagi manajer untuk meningkatkan efektifitas pengambilan keputusan yang berkaitan dengan tugas atau informasi yang memfasilitasi pengambilan keputusan yang berkaitan dengan tugas. Pengukuran variabel job relevant information menggunakan instrumen 0’Reilly yang dikembangkan oleh Kren (1992). Instrumen ini terdiri dari 4 (empat) pertanyaan, dengan rentang skor 1 (terendah) sampai dengan 5 (tertinggi).

\section{HASIL DAN PEMBAHASAN}

Responden dalam penelitian ini adalah para penyusun anggaran di tingkat Sekolah Menengah Negeri di Kota Tegal. Pengiriman kuesioner sebanyak 180 kuesioner, yang diperoleh dari 30 sekolah dikalikan dengan 6 kuesioner per sekolah. Kuesioner yang kembali sebanyak 143 kuesioner, termasuk 24 kuesioner yang tidak diisi atau diisi tetapi tidak lengkap, sehingga jumlah kuesioner yang dapat diolah sebanyak 119 kuesioner (66,11\%).

Hal pertama yang perlu dilakukan sebelum melakukan pengujian hipotesis ialah pengujian validitas dan reliabilitas kuesioner. Berdasarkan hasil pengujian validitas, seluruh pertanyaan kuesioner dinyatakan telah valid dan dapat dipergunakan untuk pengujian lebih lanjut. Selain itu pengujian reliabilitas menunjukkan hasil bahwa seluruh pertanyaan telah reliabel atau dapat dipergunakan untuk analisis lebih lanjut.

Setelah pengujian validitas dan reliabilitas kuesioner telah selesai dilakukan, maka selanjutnya akan dilakukan pengujian hipotesis penelitian. Adapun kriteria pengujian hipotesis (Ghozali, 2011) adalah sebagai berikut:

a. Nilai CR (critical ratio) $>1,96$ dengan tingkat signifikansi $<0,05$ maka berarti variabel eksogen berpengaruh terhadap variabel endogen. 
b. Nilai CR (critical ratio) < 1,96 dengan tingkat signifikansi > 0,05 maka berarti variabel eksogen tidak berpengaruh terhadap variabel endogen.

Tabel 1. Output Regression Weights

\begin{tabular}{lllrrrrl}
\hline & & & Estimate & S.E. & C.R. & P & Label \\
\hline KA & $<--$ & PPA & 0,375 & 0,189 & 1,989 & 0,047 & par_28 \\
JRI & $<---$ & PPA & 0,625 & 0,252 & 2,482 & 0,013 & par_29 \\
KO & $<---$ & PPA & 0,258 & 0,126 & 2,043 & 0,041 & par_30 \\
KM & $<---$ & KO & 0,67 & 0,333 & 2,015 & 0,044 & par_25 \\
KM & $<---$ & JRI & $-0,025$ & 0,154 & - & 0,871 & par_26 \\
KM & $<---$ & KA & $-0,015$ & 0,311 & 0,162 & 0,96 & par_27 \\
KM & $<---$ & PPA & 0,41 & 0,303 & $-0,05$ & 0,175 & par_31 \\
& & & & & 1,355 & & \\
\hline
\end{tabular}

Sumber : Hasil olah data Amos 16

Nilai estimasi standardized regression weights berfungsi sebagai uji tanda hubungan variabel eksogen terhadap variabel endogen dengan melihat nilai estimate standardized regression weights. Hal ini dapat terlihat pada Tabel 2.

Tabel 2. Output Standardized Regression Weights

\begin{tabular}{lllc}
\hline & & & Estimate \\
\hline KA & $<---$ & PPA & 0,531 \\
JRI & $<---$ & PPA & 0,572 \\
KO & $<---$ & PPA & 0,485 \\
KM & $<---$ & KO & 0,309 \\
KM & $<---$ & JRI & $-0,024$ \\
KM & $<---$ & KA & $-0,009$ \\
KM & $<---$ & PPA & 0,356
\end{tabular}

Sumber : Hasil olah data Amos 16

Hipotesis 1 menyatakan bahwa Partisipasi penyusunan anggaran berpengaruh positif terhadap kinerja manajerial. Hasil uji terhadap parameter estimasi (standardized regression weight) antara Partisipasi penyusunan anggaran terhadap kinerja manajerial menunjukkan ada hubungan positif 0,356 dengan nilai critical ratio (CR) sebesar 1,355 dengan nilai p-value 0,175. Nilai CR tersebut 
berada jauh di bawah nilai kritis \pm 1 ,96 dengan tingkat signifikansi berada di atas nilai signifikansi 0,05. Hal ini menunjukkan bahwa Partisipasi penyusunan anggaran tidak memiliki hubungan positif terhadap kinerja manajerial, sehingga hipotesis 1 tidak dapat diterima. Hasil penelitian ini sejalan dengan penelitian yang dilakukan oleh Milani (1975), Kenis (1979), Brownell dan Hirst (1986), serta Sinuraya (2009).

Berdasarkan hasil pengujian hipotesis, maka dapat disimpulkan bahwa tingginya tingkat partisipasi dalam penyusunan anggaran tidak berpengaruh signifikan terhadap kinerja manajerial. Hal ini mengindikasikan bahwa pada Sekolah Menengah Negeri, partisipasi dalam penyusunan anggaran tidak terlalu ketat adanya penekanan terhadap kinerja manajerial yang dilakukan oleh para penyusun anggaran. Penyusunan anggaran juga dianggap hanya sebagai rutinitas belaka, sehingga tidak diikuti dengan meningkatnya kinerja manajerial secara signifikan. Berbeda dengan organisasi swasta, dimana dalam penyusunan anggaran pada perusahaan swasta perlu ditekankan adanya peningkatan kinerja secara signifikan.

Hipotesis 2 menyatakan bahwa Partisipasi penyusunan anggaran berpengaruh positif terhadap kecukupan anggaran. Hasil uji terhadap parameter estimasi (standardized regression weight) antara Partisipasi penyusunan anggaran terhadap kecukupan anggaran menunjukkan ada hubungan positif 0,531 dengan nilai critical ratio (CR) sebesar 1,989, nilai p-value 0,047. Nilai CR tersebut berada di atas nilai kritis $\pm 1,96$ dengan tingkat signifikansi berada di bawah nilai signifikansi 0,05. Hal ini menunjukkan bahwa Partisipasi penyusunan anggaran berpengaruh positif terhadap kecukupan anggaran, sehingga hipotesis 2 dapat diterima. Hasil penelitian ini sejalan dengan penelitian yang dilakukan oleh Nouri dan Parker (1998), Hariyanti dan Nasir (2002), Supriyono (2004), serta Sinuraya (2009).

Berdasarkan hasil pengujian hipotesis, maka dapat disimpulkan bahwa tingginya tingkat partisipasi dalam penyusunan anggaran berpengaruh terhadap tingkat kecukupan anggaran. Hal ini mengindikasikan bahwa pada Sekolah Menengah Negeri, dengan adanya partisipasi dalam penyusunan anggaran, maka tentu saja akan diketahui dengan tepat berapa anggaran yang dibutuhkan oleh 
Sekolah, sehingga hal tersebut akan berpengaruh terhadap kecukupan anggaran yang diperlukan oleh sekolah tersebut. Saat dilibatkan dalam partisipasi penyusunan anggaran, para penyusun anggaran akan berusaha memasukkan informasi-informasi ke dalam anggaran, untuk memastikan bahwa mereka memiliki sumber-sumber yang cukup untuk menjalankan tugas-tugas mereka dengan sukses. Sehingga dengan adanya partisipasi dalam penyusunan anggaran, mereka akan memberikan informasi mengenai tingkatan sumber-sumber anggaran yang memadai.

Hipotesis 3 menyatakan bahwa Partisipasi penyusunan anggaran berpengaruh positif terhadap komitmen organisasi. Hasil uji terhadap parameter estimasi (standardized regression weight) antara Partisipasi penyusunan anggaran terhadap komitmen organisasi menunjukkan ada hubungan positif 0,485 dengan nilai critical ratio (CR) sebesar 2,043, nilai p-value 0,041. Nilai CR tersebut berada jauh di atas nilai kritis $\pm 1,96$ dengan tingkat signifikansi berada di bawah nilai signifikansi 0,05. Hal ini menunjukkan bahwa Partisipasi penyusunan anggaran berpengaruh positif terhadap komitmen organisasi, sehingga hipotesis 3 dapat diterima. Hasil penelitian ini sejalan dengan penelitian yang dilakukan oleh Chong dan Chong (2002), Hariyanti dan Nasir (2002), serta Sugioko (2012).

Berdasarkan hasil pengujian hipotesis, maka dapat disimpulkan bahwa tingginya partisipasi dalam penyusunan anggaran berpengaruh terhadap komitmen organisasi. Hal ini mengindikasikan bahwa pada Sekolah Menengah Negeri, dengan adanya partisipasi dalam penyusunan anggaran, maka tentu saja akan menambah komitmen yang dimiliki oleh para penyusun anggaran terhadap sekolah, karena mereka merasa dilibatkan dalam penentuan kebijakan sekolah, sehingga hal tersebut akan berpengaruh terhadap komitmen pada organisasi sekolah. Hal ini sesuai dengan salah satu teori hierarki kebutuhan, yaitu kebutuhan akan aktualisasi diri, dimana ketika seseorang dilibatkan dalam proses penyusunan anggaran, maka kebutuhan akan aktualisasi dirinya akan terpenuhi. Sehingga orang tersebut akan timbul perasaan memiliki atas organisasi tersebut.

Hipotesis 4 menyatakan bahwa Partisipasi penyusunan anggaran berpengaruh positif terhadap job relevant information. Hasil uji terhadap parameter estimasi (standardized regression weight) antara Partisipasi 
penyusunan anggaran terhadap job relevant information menunjukkan ada hubungan positif 0,572 dengan nilai critical ratio (CR) sebesar 2,482, nilai p-value 0,013. Nilai CR tersebut berada jauh di atas nilai kritis $\pm 1,96$ dengan tingkat signifikansi berada di bawah nilai signifikansi 0,05. Hal ini menunjukkan bahwa Partisipasi penyusunan anggaran berpengaruh positif terhadap job relevant information, sehingga hipotesis 4 dapat diterima. Hasil penelitian ini sejalan dengan penelitian yang dilakukan oleh Chong dan Chong (2002), Sardjito (2005), serta Yusfaningrum dan Ghozali (2005).

Berdasarkan hasil pengujian hipotesis, maka dapat disimpulkan bahwa tingginya partisipasi dalam penyusunan anggaran berpengaruh terhadap job relevant information. Hal ini mengindikasikan bahwa pada Sekolah Menengah Negeri, dengan adanya partisipasi dalam penyusunan anggaran, maka tentu saja akan menambah job relevant information yang dimiliki oleh para penyusun anggaran terhadap sekolah, karena mereka merasa dilibatkan dalam penentuan kebijakan sekolah, sehingga hal tersebut akan berpengaruh terhadap job relevant information pada organisasi sekolah. Partisipasi dalam penyusunan anggaran akan menumbuhkan motivasi dalam diri penyusun anggaran untuk memperoleh dan menggunakan informasi yang terbaik untuk digunakan sebagai dasar pengambilan keputusan anggaran. Dengan kata lain, para penyusun anggaran akan berpartisipasi untuk memperoleh dan menggunakan informasi yang relevan dalam rangka pengambilan keputusan anggaran yang lebih akurat.

Hipotesis 5 menyatakan bahwa Kecukupan anggaran berpengaruh positif terhadap kinerja manajerial. Hasil uji terhadap parameter estimasi (standardized regression weight) antara Kecukupan anggaran terhadap kinerja manajerial menunjukkan ada hubungan negatif -0,009 dengan nilai critical ratio (CR) sebesar $-0,05$, nilai p-value 0,96 . Nilai CR tersebut berada jauh di bawah nilai kritis $\pm 1,96$ dengan tingkat signifikansi berada di atas nilai signifikansi 0,05. Hal ini menunjukkan bahwa kecukupan anggaran tidak memiliki hubungan terhadap kinerja manajerial, sehingga hipotesis 5 tidak dapat diterima. Hasil penelitian ini sejalan dengan penelitian yang dilakukan oleh Supriyono (2004) dan Sinuraya (2009). 
Berdasarkan hasil pengujian hipotesis, maka dapat disimpulkan bahwa tingginya kecukupan anggaran tidak berpengaruh terhadap kinerja manajerial. Hal ini mengindikasikan bahwa pada Sekolah Menengah Negeri, seseorang yang ikut terlibat dalam penyusunan anggaran yang ada di organisasi sekolah tidak begitu berpengaruh terhadap kinerja manajerial, karena dalam organisasi sekolah sudah ditetapkan atau ditentukan perkiraan dana yang digunakan untuk anggaran tersebut bagi tiap-tiap sekolah, sehingga seseorang yang terlibat dalam penyusunan anggaran tersebut akan tetap membuat anggaran tersebut sesuai kebutuhan sekolah, sehingga tidak berpengaruh terhadap tinggi maupun rendahnya kinerja manajerial. Artinya bahwa sumber-sumber yang dianggarkan untuk unit organisasinya, guna mencukupi aktivitas-aktivitas yang dilakukan tidak memiliki hubungan yang signifikan terhadap peningkatan kinerja manajerial.

Hipotesis 6 menyatakan bahwa Komitmen organisasi berpengaruh positif terhadap kinerja manajerial. Hasil uji terhadap parameter estimasi (standardized regression weight) antara Komitmen organisasi terhadap kinerja manajerial menunjukkan hubungan positif 0,309 dengan nilai critical ratio (CR) sebesar 2,015, nilai p-value 0,044. Nilai CR tersebut berada jauh di atas nilai kritis $\pm 1,96$ dengan tingkat signifikansi berada di bawah nilai signifikansi 0,05. Hal ini menunjukkan bahwa Komitmen organisasi berpengaruh positif terhadap kinerja manajerial, sehingga hipotesis 6 dapat diterima. Hasil penelitian ini sejalan dengan penelitian yang dilakukan oleh Nouri dan Parker (1998), Hariyanti dan Nasir (2002), dan Supriyono (2004).

Berdasarkan hasil pengujian hipotesis, maka dapat disimpulkan bahwa tingginya komitmen organisasi berpengaruh terhadap kinerja manajerial. Hal ini mengindikasikan bahwa pada Sekolah Menengah Negeri, dengan adanya komitmen organisasi yang tinggi, maka tentu saja akan menambah kecintaan, kebanggaan, dan merasa memiliki yang dimiliki oleh para penyusun anggaran terhadap sekolah, sehingga hal tersebut akan berpengaruh terhadap kinerja manajerial yang dihasilkan. Komitmen terhadap organisasi yang kuat, maka tentu saja akan menciptakan kinerja manajerial yang tinggi.

Hipotesis 7 menyatakan bahwa Job relevant information berpengaruh positif terhadap kinerja manajerial. Hasil uji terhadap parameter estimasi 
(standardized regression weight) antara job relevant information terhadap kinerja manajerial menunjukkan hubungan negatif -0,024 dengan nilai critical ratio (CR) sebesar $-0,162$, nilai p-value 0,871 . Nilai CR tersebut berada jauh di bawah nilai kritis $\pm 1,96$ dengan tingkat signifikansi berada di atas nilai signifikansi 0,05 . Hal ini menunjukkan bahwa Job relevant information tidak memiliki hubungan terhadap kinerja manajerial, sehingga hipotesis 7 tidak dapat diterima. Hasil penelitian ini sejalan dengan penelitian yang dilakukan oleh Yusfaningrum dan Ghozali (2005).

Berdasarkan hasil pengujian hipotesis, maka dapat disimpulkan bahwa tingginya job relevant information tidak berpengaruh terhadap kinerja manajerial. Hal ini mengindikasikan bahwa pada Sekolah Menengah Negeri, suatu informasi yang diberikan oleh pegawai yang ikut terlibat dalam penyusunan anggaran di sekolah belum tentu akan dapat memberikan suatu informasi yang dibutuhkan, sebab di dalam organisasi sekolah, bagi atasan di dalam menyusun anggaran sudah bisa diperkirakan mengenai kebutuhan sekolah tersebut, sehingga untuk atasannya sendiri sudah bisa mengetahui secara langsung kondisi di sekolah, sehingga bisa mengambil keputusan apa yang harus dilakukan oleh atasan tersebut. Berbeda dengan organisasi di dalam perusahaan, memang seorang atasan dalam membuat suatu keputusan harus melibatkan banyak informasi baik dari dalam maupun luar perusahaan, karena bagi perusahaan informasi tersebut sangat penting, sebab manajemen di dalam perusahaan sangat berpengaruh terhadap kondisi perusahaan yang berhubungan kinerja yang dihasilkan, karena dalam perusahaan lebih mengutamakan pencapaian kinerja untuk perolehan laba perusahaan.

\section{SIMPULAN}

Berdasarkan analisis data penelitian, menghasilkan bahwa partisipasi penyusunan anggaran terbukti berhubungan positif terhadap kecukupan anggaran, komitmen organisasi, dan job relevant information. Sedangkan untuk partisipasi penyusunan anggaran, kecukupan anggaran, dan job relevant information tidak terbukti berhubungan positif terhadap kinerja manajerial. Hanya komitmen organisasi yang berhubungan positif terhadap kinerja manajerial. 
Penelitian ini menunjukkan bahwa partisipasi penyusunan anggaran berpengaruh positif terhadap komitmen organisasi, kemudian komitmen organisasi berpengaruh positif terhadap kinerja manajerial. Hal ini berarti bahwa komitmen organisasi memediasi hubungan antara partisipasi penyusunan anggaran terhadap kinerja manajerial. Partisipasi penyusunan anggaran tidak berpengaruh terhadap kinerja manajerial melalui kecukupan anggaran dan job relevant information.

\section{PUSTAKA ACUAN}

Brownell, and Hirst. (1986). Budgetary Participation, Motivation, and Managerial Performance. The Accounting Review, Vol. 61: 587-600.

Chong, V.K., dan Chong, K.M. (2002). “Budget Goal Commitment and Informational Effects of Budget Participation on Performance: A Structural Aquation Modeling Approach". Behavioral Research In Accounting. Vol. 14: 151-160.

Ghozali, I. (2011). Model Persamaan Struktural Konsep \& Aplikasi Dengan Program AMOS 19.0. Semarang: BP Undip.

Hariyanti, W. (2002). Pengaruh Partisipasi Penyusunan Anggaran Terhadap Kinerja Manajerial: Peran Kecukupan Anggaran Dan Komitmen Organisasi Sebagai Variabel Intervening. (Tesis Tidak Dipublikasikan). Semarang: Universitas Diponegoro.

Hariyanti, W., dan Nasir, M. (2002). Pengaruh Partisipasi Penyusunan Anggaran Terhadap Kinerja Manajerial: Peran Kecukupan Anggaran Dan Komitmen Organisasi Sebagai Variabel Intervening. Simposium Nasional Akuntansi V.

Kenis, I. (1979). The Effect of Budgetary Goal Characteristic on Managerial Attitude and Performance". The Accounting Review. Vol 54 (4): 707-721.

Milani, L. (1975). The Relationship of Participation in Budget Setting to Industrial Supervisor Performace and Attitude : a Field Study. The Accounting Review, Vol. XLX: 274-284.

Nouri, H. \& R.J. Parker. (1998). The Relationship Between Budget Participation and Job Performance The Roles of Budget Adequacy and Organizational Commitment. Accounting Organization and Society. Volume 23: 411-420. 
Nurcahyani, K. (2010). Pengaruh Partisipasi Anggaran Terhadap Kinerja Manajerial Melalui Komitmen Organisasi Dan Persepsi Inovasi Sebagai Variabel Intervening. (Skripsi Tidak Dipublikasikan). Semarang: Universitas Diponegoro.

Sardjito, B. (2005). Partisipasi Anggaran Dan Kinerja Manajer. Jurnal Ekobis. Vol. 6. No. 1: 13-25.

Sinuraya, C. (2009). Pengaruh Partisipasi Penyusunan Anggaran terhadap Kinerja Manajer: Peran Kecukupan Anggaran dan Job-Relevant Information sebagai Variabel Intervening. Jurnal Akuntansi. Vol. 1 No. 1: 17-39.

Sugioko, S. (2012). Pengaruh Komitmen dan Kecukupan Anggaran Pada Hubungan Antara Partisipasi Penganggaran dan Kinerja. Jurnal Akuntabilitas. Vol. 7 (2): 182-188.

Supriyono, R.A. (2004). Pengaruh Intervening Kecukupan Anggaran Dan Komitmen Organisasi Terhadap Hubungan Antara Partisipasi Penganggaran Dan Kinerja Manajer Di Indonesia. Jurnal Ekonomi dan Bisnis Indonesia. Vol. 19 (3): 282-298.

Yusfaningrum, K. \& I. Ghozali. (2005). Analisis Pengaruh Partisipasi Anggaran Terrhadap Kinerja Manajerial Melalui Komitmen Tujuan Anggaran dan Job Relevant Information Sebagai Variabel Intervening. Simposium Nasional Akuntansi VIII. 